\title{
Inter-annual variations of macrobenthic communities over three decades in a land-locked coastal lagoon (Santo André, SW Portugal)
}

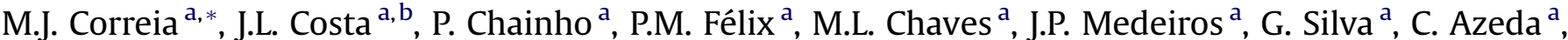 \\ P. Tavares ${ }^{\text {c }}$, A. Costa ${ }^{\mathrm{d}}$, A.M. Costa ${ }^{\mathrm{e}}$, J. Bernardo ${ }^{\mathrm{e}}$, H.N. Cabral ${ }^{\text {a,f }}$, M.J. Costa ${ }^{\text {a,f }}$, L. Cancela da Fonseca ${ }^{\text {g,h }}$ \\ ${ }^{a}$ Centro de Oceanografia, Faculdade de Ciências, Universidade de Lisboa, Campo Grande, 1749-016 Lisboa, Portugal \\ ${ }^{\mathrm{b}}$ Universidade Lusófona de Humanidades e Tecnologias, Campo Grande 376, 1749-024 Lisboa, Portugal \\ ' Instituto Superior Técnico, Centro de Geo-Sistemas/CVRM, Av. Rovisco Pais, 1049-001 Lisboa, Portugal \\ ${ }^{\mathrm{d}}$ CIEMAR - Laboratório de Ciências do Mar, Universidade de Évora, apartado 190, 7520-903 Sines, Portugal \\ ${ }^{\text {e }}$ Dep. Paisagem, Ambiente e Ordenamento, Universidade de Évora, R. Romão Ramalho 59, 7000-672 Évora, Portugal \\ ${ }^{\mathrm{f}}$ Departamento de Biologia Animal, Faculdade de Ciências da Universidade de Lisboa, Campo Grande, 1749-016 Lisboa, Portugal \\ ${ }^{g}$ CTA - Centro de Ciências e Tecnologias da Água, Universidade do Algarve, Campus de Gambelas, 8005-139 Faro, Portugal \\ ${ }^{\mathrm{h}}$ Laboratório Marítimo da Guia/Centro de Oceanografia (FCUL), Av. $N^{a}$. Sr ${ }^{a}$. do Cabo, 939, 2750-374 Cascais, Portugal
}

\section{A R T I C L E I N F O}

\section{Article history:}

Received 22 November 2011

Accepted 27 April 2012

Available online 11 May 2012

\section{Keywords:}

macrobenthic communities

land-locked coastal lagoon

ecological status

long-term changes

water framework directive

\begin{abstract}
A B S T R A C T
Santo André is an enclosed brackish water coastal lagoon with temporary connections to the sea by a man-made channel. The exchange and mixture of saltwater and freshwater is irregular and the lagoon may show daily and seasonal fluctuations, but also long-term variation. Different benthic communities may be present along the annual cycle according to the magnitude of episodic freshwater and sea water inputs.

In the last 30 years the communication with the sea has followed different regimes from year to year and, as a consequence, macrobenthic communities, assessed several times during the period before the opening to the sea, shifted from freshwater to marine affinities. Major differences were found between 1979 and 2010, with a preponderance of species with marine affinity, and the 1980s in which the organisms with freshwater affinity prevailed. Benthic communities are frequently used to assess aquatic environmental condition. Metrics used in the indices currently under discussion to assess ecological status of aquatic ecosystems within the scope of European Water Framework Directive were applied to Santo André data and the applicability of these metrics to assess quality in this coastal land-locked lagoon was discussed.
\end{abstract}

(c) 2012 Elsevier Ltd. All rights reserved.

\section{Introduction}

Coastal lagoons are important areas that provide provisioning, regulating and recreational services to coastal populations and have a high economic value (Costanza et al., 1997). They have been widely used as harbours and areas for food supply. Nowadays these aquatic systems are mainly used for aquaculture and fisheries, industrial, recreational and leisure activities, but also represent important nursery areas and feeding grounds for many itinerant marine animals and bird communities.

In a typical lagoon, the exchange and mixture of saltwater and freshwater is irregular and the hydrography may show daily,

\footnotetext{
* Corresponding author.

E-mail address: mjcorreia@fc.ul.pt (M.J. Correia).
}

seasonal and long-term fluctuations (Colombo, 1977). Biological communities in coastal lagoons are largely influenced by freshwater inputs and by mixing and exchange processes with marine areas (Barnes, 1980, 1987; Bamber et al., 1992). Nevertheless, patterns of variation in these lagoons depend on their geographical location, climatic regimes, surrounding environment, internal biogeochemical cycles and degree of communication with the sea (Barnes, 1980), which makes each lagoon as a unique system.

Coastal lagoons are particularly vulnerable to eutrophication, due to the restricted exchange with the adjacent sea and the consequent accumulation of nutrients exported by the river basin (Nowicki and Nixon, 1985; Taylor et al., 1995, 1999). They are also small systems and are therefore easily disturbed both by natural processes and by pollution or adjacent urban and industrial development (Colombo, 1977; Serpa et al., 2007 and references therein). The Environmental European Agency (EEA) designates 
such zones as physically sensitive areas (Newton et al., 2003). In coastal land-locked lagoons, their accentuated natural sensitivity is the result of the intermittency of connection with the sea.

Santo Andre is an enclosed brackish water coastal lagoon (Portuguese SW coast). The structure and dynamics of benthic communities are mainly influenced by communication with the sea and the hydrological and meteorological conditions (Cancela da Fonseca, 1989). In the last 30 years the communication with the sea has followed different regimes from year to year causing chemical and ecological fluctuations in the lagoon (Cancela da Fonseca, 1989; Cancela da Fonseca et al., 2001). The marine renewal and the maintenance of brackish characteristics are essential to the secondary productivity of the system (Cancela da Fonseca, 1989; Bernardo, 1990) and to prevent eutrophication of the lagoon and a decrease in water quality.

The importance of Santo André Lagoon (SW Portugal) for nature conservation has been recognized over the last few years (Ramsar, Special Protected Areas, European Natura 2000), reason why it was classified as a Protected Area - Reserva Natural das Lagoas de Santo André e Sancha (Santo André and Sancha Lagoons Nature Reserve) (CEZH/RNLSAS, 2004). It is also included in the transitional water systems considered for the implementation of the Water Framework Directive (WFD) (WFD, 2000/60/EC), but few studies have been conducted in this coastal lagoon since the 90 s.

Benthic communities are one of the biological elements considered by the WFD to assess ecological quality status, since they have long been used to assess quality of aquatic ecosystems (Pearson and Rosenberg, 1978; Hilly et al., 1986; Dauer, 1993; Weisberg et al., 1997; Borja et al., 2003; Chainho et al., 2007). However, their response to the highly variable and unpredictable conditions of transitional systems, including estuaries and lagoons, has been indicated as a major problem since it is difficult to separate between the effects of natural and anthropogenic stress (Elliott and Quintino, 2007). Borja et al. (2011) tested the use of single metrics and multi-metric methods and concluded that uncertainty associated to the use of multi-metric indices might result on misclassification, recommending that the performance and sensitivity of different metrics should be tested.

The goal of the study was to investigate changes in macroinvertebrate communities of Santo André coastal lagoon across 30 years and to identify the major natural stressors driving those changes. Benthic invertebrate condition was assessed using metrics included in the multi-metric index proposed to evaluate ecological status in Portuguese transitional waters, to determine their efficiency in separating the effects of natural variability and changes in human induced stress.

\section{Methods}

\subsection{Study area}

Santo André lagoon is a shallow (average annual depth of about $1 \mathrm{~m})$ land-locked coastal lagoonal system, with an area of 150-250 ha, which can double its surface during the winter period (Freitas et al., 1999). Located on the southwest coast of Portugal $\left(38^{\circ} 6^{\prime} \mathrm{N}, 8^{\circ} 48^{\prime} \mathrm{W}\right.$ ) (Fig. 1 ), it connects periodically to the sea by a man-made channel, during approximately one month in March-April and occasionally when sea water overpasses the sand barrier (usually during the Autumn-Winter period). During periodic openings, low salinity water, organic matter and sediments are exported, an increase in salinity is observed and colonization by marine species occurs (Cancela da Fonseca, 1989). During occasional openings, sea water entrance increases bottom salinity and haline stratification can be observed (Bernardo, 1990). Lagoon connection with sea is naturally closed by the sea dynamics and

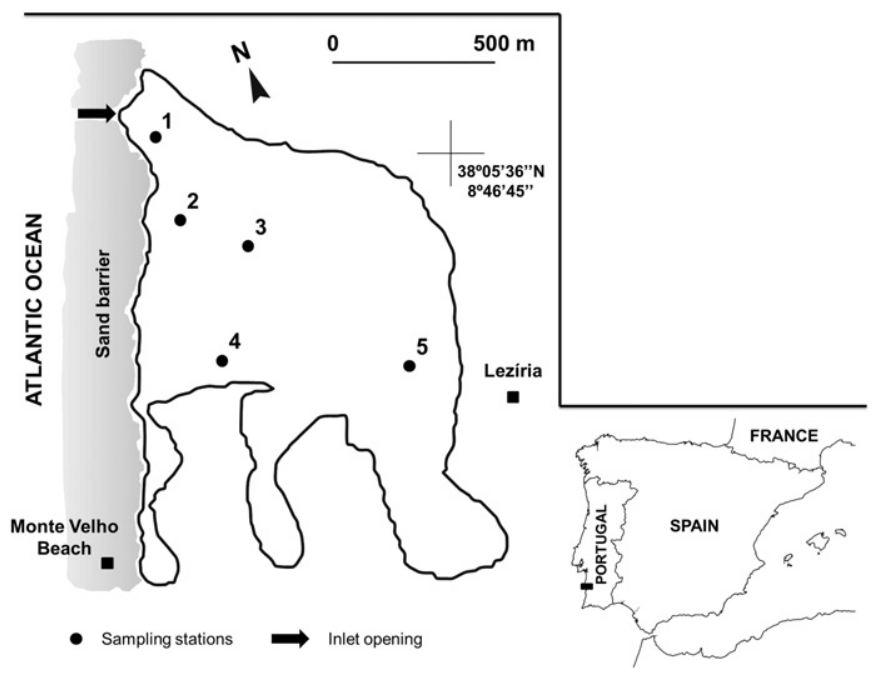

Fig. 1. Location of Santo André lagoon and sampling stations considered in the present study.

progressively, salinity decreases, organic matter accumulates and summer dystrophies may occur (Cancela da Fonseca et al., 1989).

The lagoon receives freshwater from a river basin of about $96 \mathrm{~km}^{2}$ (Bernardo, 1990). The annual shifting between an oligohaline and a polyhaline ecosystem is emphasized by the large variability of environmental and biological variables (Table 1).

Major human pressures in the Santo André lagoon watershed are agriculture runoff, livestock production (mainly pork production) and urban sewage discharges. In the last 30 years a reduction of human pressures was observed due to a decrease in livestock production and the construction of sewage treatment plants, though deficient treatment is still observed in the $\mathrm{N}$ and NE of the lagoon (CEZH/RNLSAS, 2004). The establishment of Santo André and Sancha Lagoons Nature Reserve in 2000 contributed to improve conservation and management of the area. Fishing and recreation are the main economic activities in Santo André lagoon.

\subsection{Data collection}

Five locations were sampled (Fig. 1) at Santo André lagoon in the years 1979, 1982-1985 and 2010, always before inlet opening (end of winter and early spring periods).

Sampled stations are representative of lagoon benthic habitat types, mainly characterized by a gradient of decreasing sediment grain size and salinity, from the inlet opening area towards the upstream area.

Table 1

Environmental characterization of Santo André lagoon (ranges from Bernardo, 1990).

\begin{tabular}{|c|c|}
\hline Area (ha) & $150-250$ \\
\hline Average depth (cm) & $90-280$ \\
\hline Max. depth (cm) & $225-540$ \\
\hline Salinity & $1.9-23.5$ \\
\hline Temperature $\left({ }^{\circ} \mathrm{C}\right)$ & $9.5-28.6$ \\
\hline Phosphate $\mathrm{P}-\mathrm{PO}_{4}\left(\mu \mathrm{mol} \mathrm{I}{ }^{-1}\right)$ & $0.05-3.80$ \\
\hline Nitrate $\mathrm{N}-\mathrm{NO}_{3}\left(\mu \mathrm{mol} \mathrm{1^{-1 } )}\right.$ & $0.2-75.3$ \\
\hline Ammonia $\mathrm{N}-\mathrm{NH}_{4}\left(\mu \mathrm{mol} \mathrm{l}^{-1}\right)$ & $1.4-22.3$ \\
\hline Chl $a$ concentration $\left(\mathrm{mg} \mathrm{m}^{-3}\right)$ & $1.8-61.9$ \\
\hline Macrophytes biomass (g AFDW $\mathrm{m}^{-2}$ ) & $94-438$ \\
\hline Total organic matter in the sediment (\%) & $6.5-16.6$ \\
\hline
\end{tabular}


Table 2

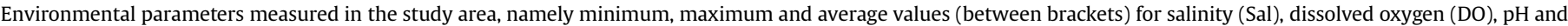

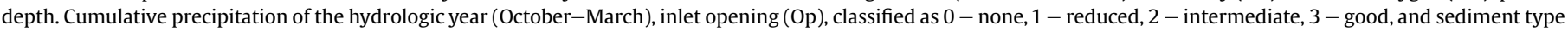
(ST) (M - mud, S - sand, MS - muddy/sand) are also displayed.

\begin{tabular}{|c|c|c|c|c|c|c|c|}
\hline & Sal & $\mathrm{DO}\left(\mathrm{mg} \mathrm{l}^{-1}\right)$ & $\mathrm{pH}$ & Depth (m) & Precipitation (mm) & Op & ST \\
\hline 1979 & $5.0-7.0(6.0)$ & $5.3-7.5(6.7)$ & - & $2.8-3.0(3.1)$ & 790.1 & 2 & $\mathrm{M}, \mathrm{S}, \mathrm{MS}$ \\
\hline 1982 & $3.0-7.5(6.3)$ & $4.8-5.6(5.1)$ & $9.1-9.3(9.2)$ & $1.0-2.0(1.6)$ & 447.0 & 0 & $\mathrm{M}, \mathrm{S}, \mathrm{MS}$ \\
\hline 1983 & $4.5-6.0(5.6)$ & $3.6-9.2(7.4)$ & $9.4-9.6(9.5)$ & $1.5-2.7(1.9)$ & 221.5 & 0 & $\mathrm{M}, \mathrm{S}$ \\
\hline 1984 & $1.6-2.0(1.8)$ & $6.6-8.0(7.3)$ & $6.4-8.0(7.4)$ & $0.7-2.4(1.5)$ & 650.9 & 1 & M, S, MS \\
\hline 1985 & $1.3-7.6(5.1)$ & $0.2-7.0(2.7)$ & $7.3-7.6(7.3)$ & $2.6-4.1(3.2)$ & 703.6 & 1 & $\mathrm{M}, \mathrm{S}, \mathrm{MS}$ \\
\hline 2010 & 2.3 & $9.5-10.1(9.8)$ & - & $3.5-4.0(3.8)$ & 616.9 & 3 & $\mathrm{M}, \mathrm{S}, \mathrm{MS}$ \\
\hline
\end{tabular}

Samples were collected at each sampling station (3 spatial replicates at each station) using a Birg-Ekman or a van-Veen grab $\left(0.05 \mathrm{~m}^{2}\right)$. Stations 2 and 3 were not sampled in 1979 and station 3 was not sampled in 1983. Additional grabs were collected for sediment grain size determination. Salinity, dissolved oxygen, $\mathrm{pH}$ and depth were measured in situ using a multiparametric probe.

Samples were fixed using $4 \%$ buffered formalin and later washed through a $1 \mathrm{~mm}$ mesh sieve and preserved in 70\% ethanol. Specimens were sorted, identified to the lowest practical taxonomic level and counted. Sediment grain size composition was obtained according to Buller and McManus (1979) and classified with Shepard diagram (Buchanon and Kain, 1971) as sand, muddy sand/ sandy mud and mud.

A qualitative nominal classification ranging from 0 to 3 ( $0=$ none; $1=$ reduced $2=$ intermediate; $3=$ good $)$ was attributed to the inlet opening of each year. Classifications for each year were based on the time, duration and intensity of the inlet opening in the previous year, which influences subsequent environmental conditions and the observed benthic community. Precipitation data was obtained from the nearest meteorological station (Grândola) (www.snirh.pt).

\subsection{Data analyses}

Spatial and temporal differences on the benthic invertebrate community were assessed using a Permutational Analysis of Variance (PERMANOVA) (Anderson, 2005), with a two-way fixed-effect crossed design (Factors: sampling period (1979, 1982, 1983, 1985 and 2010) - Year; and sampling site - Station) (for sampling sites see Fig. 1). Replicate samples were $\log$ transformed $(\log X+1)$ and Bray-Curtis zero-adjust similarity coefficient was used as resemblance measure, due to replicates with zero observations (Clarke et al., 2006). These procedures were performed using PRIMER ${ }^{\circledR}$ v6.

A Canonical Correspondence Analysis (CCA) (ter Braak, 1986) was performed to investigate temporal patterns of benthic invertebrate community (considering the different sampling sites in each year) and relate it with environmental variables. Environmental variables were selected through a manual forward selection using a Monte Carlo permutation test $(p<0.01)$. A global Monte Carlo permutation test was used to determine the significance $(p<0.01)$ of the first ordination axis and the sum of all canonical axes. CCA was carried out using Canoco v4.5 (Biometris ${ }^{\circledR}$ ).

Macrobenthic invertebrate community structure was analysed regarding density $(N)$ (ind. $\mathrm{m}^{-2}$ ), taxonomic richness (number of taxa) (S), Margalef richness (d) (Margalef, 1969) and the Shannon-Wiener diversity $\left(H^{\prime}-\log _{2}\right)$ (Shannon and Weaver, 1963). AMBI v4.1 (AZTI's Marine Biotic Index) (Borja et al., 2000) was also calculated based on the February 2010 updated species list available on the AMBI v4.1 program (http://ambi.azti.es). The default values for the reference conditions given by the AZTI application were used. Taxa not included in the AMBI classification list were assigned based on an equivalent score of the freshwater biotic index IBMWP (Iberian Bio-monitoring Working Party), whenever possible (Alba-Tercedor and Sánchez-Ortega, 1988; Alba-Tercedor et al., 2002; Medeiros et al., 2011) (Appendix A). Analyses of variance (one-way ANOVA) with Tukey's post hoc comparisons tests were used to assess temporal differences on the benthic community metrics, considering each sampling site as a replicate and using STATISTICA v10 software.

Generalized linear modelling (GLM) was used to model the community structure parameters as a function of the environmental factors, considering all the replicates. GLM is a regression model less rigid than classical linear regression and may be applied to data that are not necessarily normally distributed (McCullagh and Nelder, 1989). Community metrics ( $S, N, H^{\prime}, d$ and AMBI) were modelled as a function of year, station, sediment type, opening, salinity, depth, dissolved oxygen and precipitation. $\mathrm{pH}$ was not included in these analyses due to some missing values. The goodness-of-fit of the models was assessed by comparing their relative contribution to total deviance explained. The model was fitted in R environment ( $R$ Development Core Team, 2005) using a Gamma distribution with a log-link function, adding the firstorder interactions whenever considered adequate. A significance level of 0.05 was retained for all test procedures.

\section{Results}

\subsection{Environmental variables}

Environmental parameters measured in the study area varied between years (Table 2). Samples were collected before inlet opening and after the precipitation period, therefore the lagoon salinity was generally low due to winter freshwater inputs, with average values ranging from 1.8 in 1984 to 6.3 in 1982.

\subsection{Community composition and abundance}

A total of 42 taxa were identified in the Santo André lagoon and major taxonomic groups identified were Insecta (13 taxa), Polychaeta (6 taxa), Gastropoda (5 taxa), Bivalvia (5 taxa), Amphipoda (2 taxa) and Isopoda ( 2 taxa). Chironomidae was the most abundant taxon accounting for $26 \%$ of total abundance, followed by the amphipod Gammarus chevreuxi (20\%), the isopod Lekanesphaera hookeri (13\%), Oligochaeta (12\%), Cerastoderma spp. (12\%) and Abra segmentum (10\%). Together, these taxa accounted for $94 \%$ of total abundance. These were also the most frequent taxa, since Chironomidae were observed in $86 \%$ of the samples, L. hookeri in $44 \%, G$. chevreuxi in 39\%, Oligochaeta in 34\%, Hediste diversicolor in $32 \%$ and A. segmentum in $22 \%$. The remaining species occurred in less than $20 \%$ of the samples.

\subsection{Variations in community composition and structure}

The PERMANOVA tests showed a high spatial-temporal variability (significant differences within each factor and significant interactions between the two factors) in the macrobenthic 
community of the study area (Table 3). Pairwise comparisons revealed significant differences between all years and sampling stations ( $p<0.05$ ), except between stations 1 and 4 and between stations 4 and 5 .

CCA revealed that the degree of inlet opening, salinity, depth, dissolved oxygen and precipitation (rain) were the environmental variables that best explained the variability of biological communities of the Santo André lagoon along the studied years (Fig. 2). The first two axes of the CCA ordination explained $14.3 \%$ of taxa temporal variability and $49.3 \%$ of the relationship between their density and the selected environmental variables. The global permutation tests showed that the relations between taxa abundance and environmental variables for the first canonical axis $(F-$ ratio $=7.127)$ and for the sum of all canonical axes $(F$-ratio $=3.347)$ are statistically significant $(p<0.01)$.

CCA ordination showed four major different groups based on the benthic community patterns, mainly associated with different years (Fig. 2). Group I (GI) includes Cerastoderma spp., Scrobicularia plana, Abra segmentum, and Hediste diversicolor among others and it is related to a better inlet opening and higher values of dissolved oxygen, depth and precipitation, and is mostly associated with the 2010 samples. Group II (GII) includes Potamopyrgus antipodarum, Lekanesphaera hookeri and several insect species, mainly collected in 1982, 1983 and 1985, associated to higher salinities. A third group (Group III - GIII) consists mainly of samples collected in 1984, characterized by higher abundance of insect species and associated to lower salinities. These two groups seem to be inversely related to the degree of inlet opening, dissolved oxygen, depth and precipitation. Group IV (GIV) includes samples characterized by the abundance of Cyathura carinata, Hydrobia ulvae and Mytilus galloprovincialis (GIV) and, although being favoured by the same environmental characteristics as GI, is associated to the higher salinity values registered in 1979 .

In spite of being abundant in all the studied period, Chironomidae and Gammarus chevreuxi showed a higher affinity with the 1980s samples, characterized by a lower water renewal of the lagoon during those years, while Oligochaeta were more characteristic in 2010 samples. All these taxa were less abundant in 1979.

Community structure measures presented high temporal variation and were significantly different between the studied years, though showing similar trends, with lower values in 1979 and 1980s, and higher values in 2010 (Fig. 3 and Table 4). GLMs showed that depth and sediment type were the most important explanatory variables for taxa richness and density, and these models explained $6 \%$ and $13.5 \%$ of the deviance, respectively (Table 5 ). Highest values of these metrics were observed with increasing depth and presence of sand. Depth was also the best explanatory variable for Shannon-Wiener and Margalef indices trends (1.45\% and $2.22 \%$ of deviance explained, respectively), which showed higher values with increasing depth (Table 5).

In the Santo André lagoon AMBI mean values ranged from 1.97 (1983) to 3.82 (1979) (Fig. 3), indicating that benthic community health ranged from unbalanced (1982-1985) to transitional to pollution (1979 and 2010). In 1979 and 1985 the lagoon benthic community classification ranged from unbalanced to heavily polluted (different sampling stations), reflecting the variability of faunal composition in those years, regarding their sensibility to

Table 3

Results from the two fixed factor PERMANOVA tests performed to compare macrobenthic community in the different years and sampling sites.

\begin{tabular}{lrlllll}
\hline Source & df & SS & MS & Pseudo- $F$ & $P($ perm $)$ & Perms \\
\hline Year & 5 & 73569 & 14714 & 14.005 & 0.001 & 999 \\
Sites & 4 & 15112 & 3778.1 & 3.5962 & 0.001 & 999 \\
Year $\times$ Sites & 17 & 48376 & 2845.7 & 2.7087 & 0.001 & 999 \\
\hline
\end{tabular}

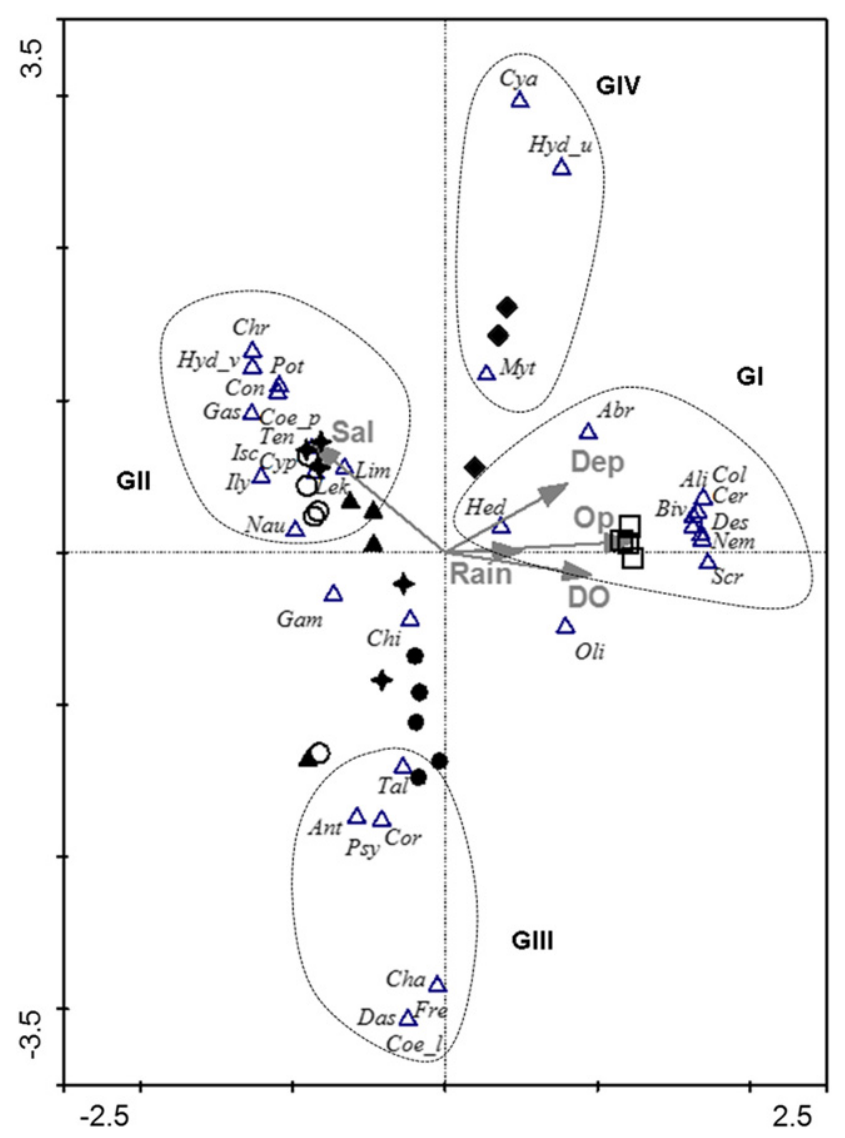

Fig. 2. CCA ordination triplot diagram showing samples (years/sites), taxa identified and explanatory environmental variables. Years are represented by: $-79, \bigcirc-82$, $\Delta-83,-84, \downarrow-85, \square-10$. Taxa are represented by open triangles and environmental variables indicated by arrows. Abr - Abra segmentum; Ali - Alitta succinea; Ant - Anthomyidae; Biv - Bivalvia; Cer - Cerastoderma spp.; Cha - Chaoborus sp; Chi - Chironomidae; Chr - Chrysomelidae; Coe_l - Coenagrion lindeni; Coe_p - Coenagrion pulchellum; Col - Collembola; Con - Conopeum seurati; Cor - Cordylophora caspia; Cya - Cyathura carinata; Cyp - Cyprideis littoralis; Das - Dasyhelea sp.; Des Desdemona ornata; Fre - Fredericella sultana; Gam - Gammarus chevreuxi; Gas Gastropoda; Hed - Hediste diversicolor; Hyd_u - Hydrobia ulvae; Hyd_v - Hydrobia ventrosa; Isc - Ischnura graellsi; Lek - Lekanesphaera hookeri; Lim - Limoniidae; Myt Mytilus galloprovincialis; Nau - Naucoris maculatus; Nem - Nemertea; Pot - Potamopyrgus antipodarum; Psy - Psychodidae; Scr - Scrobicularia plana; Tal - Talorchestia deshayesii; Ten - Tenella palida; Oli - Oligochaeta; Ily - Ilyocoris cimicoides. Dep depth; DO - dissolved oxygen; Op - inlet opening; Rain - cumulative precipitation of hydrologic year; Sal - salinity.

disturbance/pollution. During the studied period lagoon faunal composition was dominated by tolerant species (Chironomidae, Lekanesphaera hookeri and Abra segmentum), and in 2010 an increase of first-order opportunistic species (e.g. Oligochaeta) was observed. Precipitation was the best explanatory variable for the AMBI index trends (9.9\% of variance explained), since the index increased with higher precipitation (Table 5).

\section{Discussion}

Santo André lagoon is artificially connected with the sea once a year in late winter/spring, for a short period of about one month. In the past 30 years inlet opening varied from absence to full connection, mainly due to administrative problems. The connection with the sea had major influence on the environmental conditions of the lagoon, and its regime in the 1980s lead to an eutrophication of the lagoon. Lower dissolved oxygen values occurred in those years, when compared to 2010, when a good inlet opening 

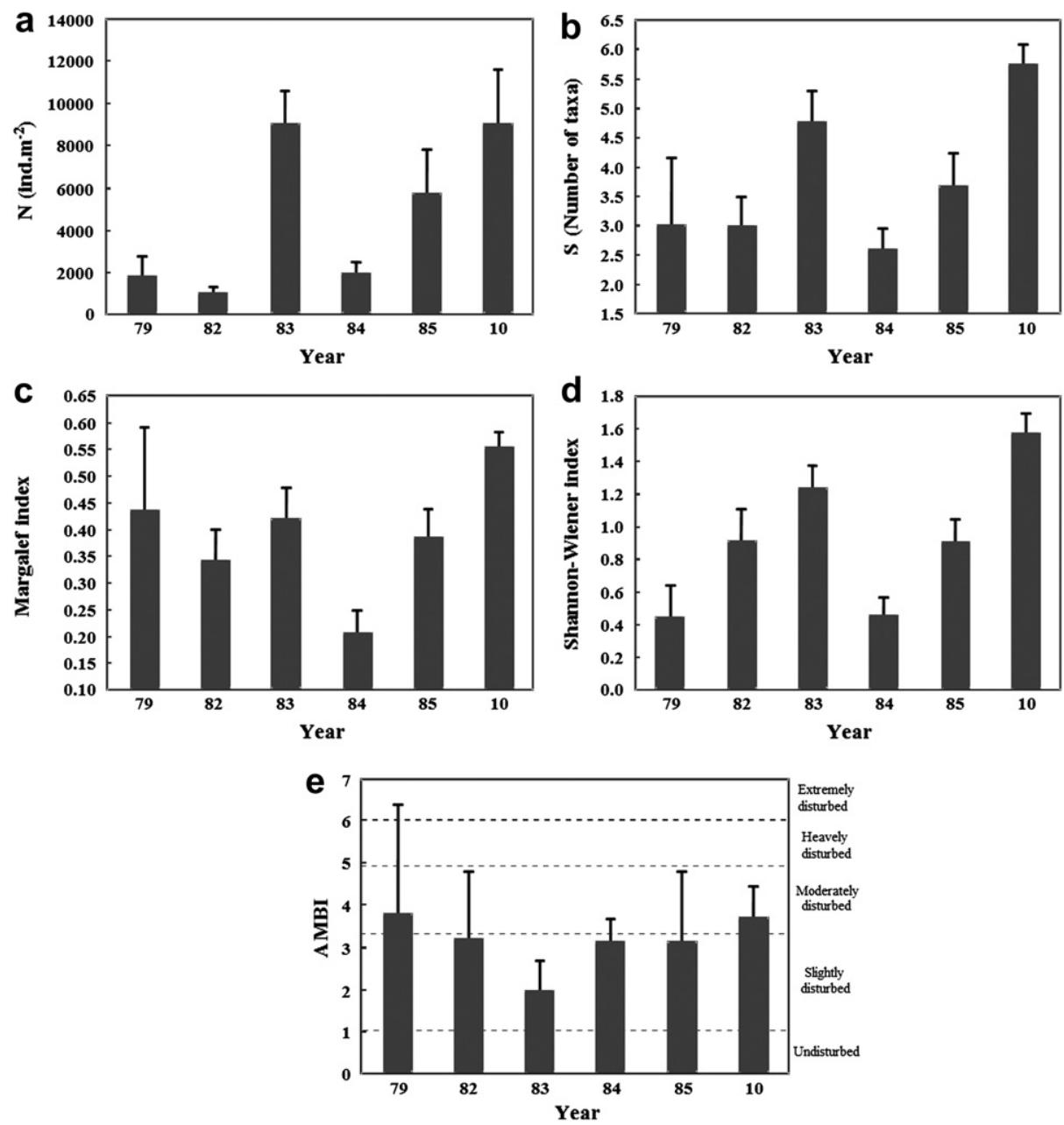

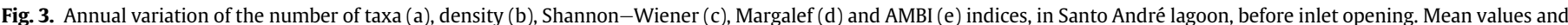
standard errors (standard deviation for AMBI) considering all sampling sites are presented.

occurred. Eutrophication processes in Santo André lagoon are well documented (Cancela da Fonseca, 1989; Bernardo, 1990; Cancela da Fonseca et al., 2001) and the annual renewal of the lagoonal environment, promoted by the connection with the sea, plays a major role to prevent Santo André lagoon from turning into an eutrophic freshwater pond and ensures the maintenance of its brackish characteristics (Cancela da Fonseca et al., 2001).

\section{Table 4}

Results of the statistical tests (one-way ANOVA and post hoc Tukey HSD) performed to compare community structure measures in the different years sampled. Only significant differences between years are shown.

\begin{tabular}{llrlll}
\hline & & df & MS & F-ratio & Post hoc tests \\
\hline Number of taxa & Year & 5 & 20.821 & $5.135^{* * *}$ & $84 \mathrm{vs} 83^{*}$ \\
& Error & 75 & 4.055 & & $84 \mathrm{vs} 10^{* * *}$ \\
& & & & & $10 \mathrm{vs} 82^{*}$ \\
Density & Year & 5 & $1.8 \mathrm{E} \times 10^{-8}$ & $4.910^{* * *}$ & $82 \mathrm{vs} 83^{*}$ \\
& Error & 75 & $3.7 \mathrm{E} \times 10^{-7}$ & & $84 \mathrm{vs} 10^{*}$ \\
& & & & & $10 \mathrm{vs} 82^{*}$ \\
Shannon-Wiener & Year & 5 & 2.518 & $7.706^{* * *}$ & $84 \mathrm{vs} 83^{* *}$ \\
index & Error & 75 & 0.329 & & $84 \mathrm{vs} 10^{* * *}$ \\
& & & & & $10 \mathrm{vs} 79^{*}$ \\
Margalef index & Year & 5 & 0.192 & $4.762^{* * *}$ & $84 \mathrm{vs} 10^{* * *}$ \\
& Error & 68 & 0.040 & & \\
\hline
\end{tabular}

${ }^{* * *} p<0.001,{ }^{* *} p<0.01,{ }^{*} p<0.05$
The annual dynamics of water renewal in Santo André lagoon and the inherent year-to-year variability of physical conditions in lagoons (Barnes, 1980; Desmond et al., 2002) lead to a high temporal variability in biological communities (phytoplankton community - Duarte et al., 2006; Ruppia cirrhosa - Calado and Duarte, 2000; benthic community, as it was found in this study). Benthic community sampled in the present study consisted of 42 taxa, most of which are typical of these lagoonal systems (e.g. Abra segmentum, Cerastoderma spp., Gammarus chevreuxi, Chironomidae, Lekanesphaera hookeri, Hediste diversicolor) (Muus, 1967; Barnes, 1980; Guelorget and Perthuisot, 1983), with a wide range of distribution, from the Atlantic to the Mediterranean and Ionian Sea (Bachelet et al., 2000; Koutsoubas et al., 2000; Mistri et al., 2000, 2001) and also present in other Portuguese lagoons (Quintino and Rodrigues, 1989; Cunha and Moreira, 1993; Cancela da Fonseca et al., 1999; Costa et al., 2003; Gamito, 2008; Carvalho et al., 2011), emphasizing their resilience, and ability to colonise systems with very distinct characteristics. Moreover, several taxa in this study, including some of the most abundant, such as Oligochaeta and several Diptera families (e.g. Chironomidae), are considered as opportunistic, while others are stress tolerant species, namely $H$. diversicolor, $A$. segmentum and $L$. hookeri (Pearson and Rosenberg, 1978; Alba-Tercedor and Sánchez-Ortega, 1988; Grall and Glémarec, 1997; Borja et al., 2000), and therefore benefit from the highly stressful conditions in this lagoon. 
Table 5

Goodness-of-fit statistics for the GLMs fitted to taxa richness $(S)$, density $(N)$, and Shannon-Wiener $\left(H^{\prime}\right)$, Margalef $(d)$ and AMBI indices. Values of deviance for each factor, residual deviance (Res. Dev.), and percentage of the total deviance explained by each factor (\% Expl.) are displayed.

\begin{tabular}{|c|c|c|c|c|}
\hline & Predictor & Deviance & Res. Dev & \% Expl. \\
\hline \multirow[t]{5}{*}{$S$} & NULL 156.86 & & & \\
\hline & Main effects & & & \\
\hline & Depth** & 4.06 & 152.8 & 2.588 \\
\hline & Sand* & 1.81 & 155.05 & 3.436 \\
\hline & Total explained & & & 6.024 \\
\hline \multirow[t]{6}{*}{$N$} & NULL 342.07 & & & \\
\hline & Main effects & & & \\
\hline & Sand** & 23.92 & 318.15 & 6.993 \\
\hline & Depth* & 12.73 & 329.34 & 4.742 \\
\hline & DO & 13.71 & 328.36 & 1.786 \\
\hline & Total explained & & & 13.521 \\
\hline \multirow[t]{4}{*}{$H^{\prime}$} & NULL 286.25 & & & \\
\hline & Main effects & & & \\
\hline & Depth** & 4.14 & 282.11 & 1.446 \\
\hline & Total explained & & & 1.446 \\
\hline \multirow[t]{4}{*}{$d$} & NULL 246.66 & & & \\
\hline & Main effects & & & \\
\hline & Depth* & 5.48 & 241.18 & 2.222 \\
\hline & Total explained & & & 2.222 \\
\hline \multirow[t]{4}{*}{ AMBI } & NULL 20.22 & & & \\
\hline & Main effects & & & \\
\hline & Precipitation** & 2.01 & 18.21 & 9.941 \\
\hline & Total explained & & & 9.941 \\
\hline
\end{tabular}

Two main periods were distinguished in the last 30 years in the Santo André lagoon based on the macrobenthic community pattern identified by the multivariate analysis, a pre- and post-1980s period dominated by lagoonal and of marine origin taxa and the 80s dominated by lagoonal and continental taxa, reflecting the influence of the sea inlet opening. This pattern illustrates the role of the confinement, determined by the annual sea water renewal and the lagoon colonization by species of marine origin, which according to Guelorget and Perthuisot (1983) primarily determines the composition of biological communities in lagoonal ecosystems. In 1979/2010 community was characterized by Hediste diversicolor, Desdemona ornata (only on 2010), Cerastoderma spp., Abra segmentum, Hydrobia ulvae (only in 1979), Lekanesphaera hookeri and Chironomidae, while in the 1980s the benthic community was dominated by $H$. diversicolor, Potamopyrgus antipodarum, L. hookeri, Gammarus chevreuxi, Chironomidae, freshwater bryozoans and a great number of insect taxa. The latter period showed limnetic affinities and therefore marine species which cannot tolerate very low salinities (e.g. Polydora hoplura, Cyathura carinata and H. ulvae) were absent from the lagoon community.

Some differences were also registered between 1979 and 2010, namely the occurrence of Polydora ciliata, Polydora hoplura, Ceratonereis hircinicola and Mytilus galloprovinciallis in 1979 and Desdemona ornata, Alitta succinea and Scrobicularia plana in 2010. These differences are possibly related with the different patterns of reproduction of these species and their larval availability in the coastal area during lagoon opening (Zajac and Whitlatch, 1982).

In general, higher insect taxa diversity occurred in the 1980 s revealing some constraint for their settlement during years characterized by stronger sea water entrance in the lagoon. Some insect taxa are less tolerant to salinity increase (e.g. Coenagrion lindeni, Dasyhelea sp., Psychodidae, Anthomyidae) (GIII in CCA) (Piscart et al., 2005) and occurred only in 1984 when Santo André lagoon showed a pronounced limnetic state. The hydrozoa Cordylophora caspia was also observed only in the 1980s, confirming its "preference" for oligohaline conditions as observed by Muus (1967).
The abundance and occurrence patterns of some of the most representative species in the lagoon community, namely Hydrobiidae and Gammarus chevreuxi, corroborate the previously mentioned differences between periods, but also the year-to-year variability. The distribution of Hydrobiidae (Hydrobia ulvae, Hydrobia ventrosa and Potamopyrgus antipodarum) was studied by Muus (1967) in Danish estuaries, which pointed out that these species have distinct demands concerning water movement and salinity. Hydrobia ulvae prefers a more continuous renewal of water and higher salinities, while $H$. ventrosa and $P$. antipodarum occur in quieter waters with lower salinities. This is consistent with this study since $H$. ulvae was confined to the samples collected in 1979 and 2010, although more abundant in the first year when salinities were higher, and was replaced by $H$. ventrosa and $P$. antipodarum in the 1980s when salinities were lower and less water renewal occurred. On the other hand, the amphipod G. chevreuxi was very abundant in the 1980s which was probably related with the increase in macrophytes biomass recorded for this period (Cancela da Fonseca, 1989), since abundance peaks for this species are related with high food availability (Subida et al., 2005). Fluctuations observed for this species could also be related to migration patterns, explaining the abundance decrease in 1984 and the disappearance from 2010 samples. This species migrates to freshwater areas in winter months (Subida et al., 2005) occurring in the brackish waters mainly during the reproduction periods (Dieleman, 1979).

Benthic community structure in Santo André lagoon is characterized by the dominance of few species and low diversity, in accordance with the normally observed for these natural stressed systems (Elliott and Quintino, 2007). In the first years of the non-opening period (82 and 83) an increase in the number of taxa, diversity and density occurred, comparatively to 1979 , mainly driven by the lagoon colonization by freshwater species and the persistence of species of marine origin (e.g. Abra segmentum). Nevertheless, the maintenance of limnetic conditions in 1984 led to the disappearance of the species with marine affinity, and consequently a drastic decrease of those metrics was observed, revealing that inlet closure for long periods has negative effects on diversity (Desmond et al., 2002). In 1985 the benthic community seemed to be evolving towards the situation observed in 1979, and in 2010 higher number of taxa, diversity and density were observed, emphasizing the fact that the annual connection with sea enables the lagoon colonization with species of marine origin. As stated for island systems, biological diversity in Santo André lagoon is a function of species immigration and extinction rates (MacArthur, 1972; Diamond and May, 1976).

The results of this study highlight the importance of sediment type and depth as structuring factors for the benthic community. The number of taxa, density and diversity increased in higher depths and sandy bottoms, which are the prevailing conditions near the inlet opening. This is in agreement with patterns already identified by Cancela da Fonseca (1989) in this lagoon, showing a negative correlation between species diversity and the distance to the inlet opening. Additionally, this is the area with lowest organic enrichment in the lagoon, and therefore an increase in the number of species is expected (Pearson and Rosenberg, 1978), as well as an increase in diversity as described for the Orbetello lagoon (Lardicci and Rossi, 1998).

The application of the marine biotic index AMBI to the Santo André lagoon macrobenthic community in the studied period, showed that the system ranged from a meanly polluted condition in the years when an effective sea connection occurred, to a slightly polluted condition in the non-opening period. In the former period, a clear dominance of taxa assigned to ecological group III was observed, comprising species that are tolerant to organic enrichment (Grall and Glémarec, 1997) and their dominance is considered characteristic of estuarine communities from sites with organic matter inputs (Borja et al., 2000). In the second period, though the 
lagoon has been in a more eutrophic state its salinity gradient favoured the presence of Cordylophora caspia and Gammarus chevreuxi, which are sensitive species, typical from undisturbed conditions, the last being one of the dominant species in the 1980s.

Considering that Santo André lagoon is included in the Portuguese Network of Protected Areas since 2000, and that the main human pressures have been reduced, an improvement or at least the maintenance of the benthic condition would be expected in 2010 rather than the observed decrease. Similarly to what was found by Chainho et al. (2007) in the Mondego estuary, it seems that Margalef and Shannon-Wiener indices respond better to the environmental changes in the lagoon than AMBI. On the other hand, GLM reveals that precipitation was the factor that better explained the AMBI trend, with rainy years showing lower benthic condition. Since freshwater is the main source of nutrients and raw materials for lagoon ecosystems, the increase in precipitation is expected to decrease lagoon environmental condition.

Although methods to assess quality using benthic communities have already been established in the scope of the WFD, the choice of indices and reference conditions considering the variety of coastal and transitional ecosystems in Europe have been discussed by several authors (Quintino et al., 2006; Chainho et al., 2007; Dauvin, 2007; Pinto et al., 2009; Borja et al., 2011). These authors recognize that a single benthic index should be applied carefully, attending to different sensitivity of species to anthropogenic disturbance, and acknowledge that a benthic index is unlikely to be universally applicable, since organisms are not equally sensitive to natural and anthropogenic disturbance and thus are likely to respond differently to different types of disturbance. Since reference conditions are not defined for the mesotidal semi-enclosed lagoon typology, in which Santo André was classified in the scope of WFD, the present assessment of Santo André lagoon benthic condition should be regarded with caution. First of all because the robustness of AMBI index is reduced when only a very low number of taxa (1-3) and/or individuals are found in a sample (Borja et al., 2004), or in areas with strong salinity gradients (Zettler et al., 2007), such as observed in the Santo André lagoon. Additionally, there is a lack of consistent monitoring of the benthic community of Santo André lagoon as well as insufficient ecological information on most of the lagoonal species and their responses to physical and anthropogenic stress. Therefore, the assessment of the ecological status of the Santo André lagoon using the methods proposed for Portuguese transitional waters requires adaptations that account for specific characteristics of coastal lagoons. These adaptations might include (i) the exclusion of metrics that do not show predictable responses to human induced stress, (ii) the definition of habitat type specific reference conditions and (iii) the selection of specific environmental conditions related to the lagoon opening regime for benthic monitoring.

\section{Conclusions}

The present study showed that major patterns identified on macroinvertebrate communities of a land-locked coastal lagoon are mainly related to physical factors such as depth and sediment, which are directly related to the distance from the inlet opening. Additionally, inlet opening regime is also determinant for inter-annual changes observed on the benthic structure along the last 30 years.

Among Portuguese coastal lagoons, Santo André lagoon is one of the less disturbed lagoonal systems, since a considerable reduction on human pressures was implemented after its classification as a protected area. This improvement supports the use of this system to derive type specific reference conditions in the aim of the WFD. Nevertheless, in a very unpredictable and changing environment, with pronounced inter-annual and spatial differences, indices currently used to assess ecological status based on macrobenthic communities do not seem to be able to separate natural variations occurring in this enclosed lagoons from those resulting from human pressures, requiring further development/adaptation of the available assessment tools.

\section{Acknowledgements}

The authors acknowledge the research funding for the project "Structure, dynamic and production of estuarine and costal lagoon ecosystems" funded by the National Institute of Scientific Research; for the project "Baseline studies for the physic, chemical and biological characterization of coastal lagoon biotopes from Santo André, Melides and Sancha lagoons" funded by ICNB (Nature, Conservation and Biodiversity Institute) and EEC (European Economic Community); for the project "Ecological status assessment of coastal and transitional waters and ecological potential assessment of heavily modified water bodies" (EEMA), funded by Cohesion Fund under Priority III of the Operational Programme for Territorial Development (POVT); for the project "Modeling scenarios of exploitation in coastal aquifers: effects on biodiversity of lagoons and their streams as groundwater dependent ecosystems - GroundScene" - PTDC/AAC-AMB/104639/2008, for the project PEst-OE/MAR/UI0199/2011, funded by FCT (Science and Technology Foundation); and for the Post Doc fellowship SFRH/ BPD/29579/2006 funded by FCT. Thanks are also due to Célia Teixeira for the help with statistical analysis.

\section{Appendix A}

Taxa assignment to the ecological groups used for the AMBI calculation based on an equivalent score of the Iberian Biomonitoring Working Party (IBMWP)

\begin{tabular}{lc}
\hline Taxa & AMBI \\
\hline Phylum ARTHROPODA & \\
Anthomyiidae & IV \\
Chrysomelidae & IV \\
Coenagrion pulchellum (Vander Linden, 1825) & III \\
Coenagrion sp. & III \\
Dasyhelea sp. & IV \\
Ischnura graellsii (Rambur, 1842) & III \\
Limoniidae & IV \\
Naucoris maculatus Fabricius, 1798 & IV \\
Psychodidae & IV \\
\hline
\end{tabular}

\section{References}

Alba-Tercedor, J., Sánchez-Ortega, A., 1988. Un método rápido y simple para evaluar la calidad biológica de las aguas corrientes basado en el de Hellawell (1978). Limnetica 4, 51-56.

Alba-Tercedor, J., Jáimez-Cuéllar, P., Álvarez, M., Avilés, J., Bonada, N., Casas, J., Mellado, A., Ortega, M., Pardo, I., Prat, N., Rieradevall, M., Robles, S., Sáinz-Cantero, C.E., SánchezOrtega, A., Suárez, M.L. Toro, M., Vidal-Abarca, M.R., Vivas, S., Zamora-Muñoz, C., 2002. Caracterización del estado ecológico de rios mediterráneos ibéricos mediante el índice IBMWP (antes BMWP'). Limnetica 21, 175-185.

Anderson, M.J., 2005. PERMANOVA: A FORTRAN Computer Program for Permutational Multivariate Analysis of Variance. Department of Statistics, University of Auckland, New Zealand, 24 pp.

Bachelet, G., de Montaudouin, X., Auby, I., Labourg, P.-J., 2000. Seasonal changes in macrophyte and macrozoobenthos assemblages in three coastal lagoons under varying degrees of eutrophication. ICES Journal of Marine Science 57, 1495-1506.

Bamber, R.N., Batten, S.D., Sheader, M., Bridgwater, N.D., 1992. On the ecology of brackish water lagoons in Great Britain. Aquatic Conservation: Marine and Freshwater Ecosystems 2, 65-94.

Barnes, R.S.K., 1980. Coastal lagoons. The natural history of a neglected habitat. In: Cambridge Studies in Modern Biology: 1. Cambridge University Press, Cambridge, $\mathrm{xi}+106 \mathrm{pp}$.

Barnes, R.S.K., 1987. Coastal lagoons of East Anglia, U.K. Journal of Coastal Research 3, $417-427$ 
Bernardo, J.M., 1990. Dinâmica de uma lagoa costeira eutrófica (Lagoa de Santo André). Ph.D. thesis, University of Lisbon, Portugal, unpublished.

Borja, A., Barbone, E., Basset, A., Borgersen, G., Brkljacic, M., Elliott, M., Garmendia, J.M., Marques, J.C., Mazik, K., Muxika, I., Neto, J.M., Norling, K., Rodríguez, J.G., Rosati, I. Rygg, B., Teixeira, H., Trayanova, A., 2011. Response of single benthic metrics and multi-metric methods to anthropogenic pressure gradients, in five distinct European coastal and transitional ecosystems. Marine Pollution Bulletin 62, 499-513.

Borja, A., Franco, J., Muxika, I., 2004. The biotic indices and the water framework directive: the required consensus in the new benthic monitoring tools. Marine Pollution Bulletin 48, 405-408.

Borja, A., Franco, J., Pérez, V., 2000. A marine biotic index to establish the ecological quality of soft-bottom benthos within European estuarine and coastal environments. Marine Pollution Bulletin 40, 1100-1114.

Borja, A., Muxika, I., Franco, J., 2003. The application of a marine biotic index to different impact sources affecting soft-bottom benthic communities along European coasts. Marine Pollution Bulletin 46, 835-845.

Buchanon, J.B., Kain, J.M., 1971. Measurement of the physical and chemical environment. In: Holme, N.A., McIntyre, A.D. (Eds.), Methods for the Study of Marine Benthos. IBP Handbook $\mathrm{N}^{\circ} 16$. Blackwell Scientific Pub, Oxford, pp. 30-58.

Buller, A.T., McManus, J., 1979. Sediment sampling and analysis. In: Dyer, K.R. (Ed.), Estuarine Hydrography and Sedimentation. A Handbook. Cambridge University Press, London, 230 pp.

Calado, G.J.P., Duarte, P., 2000. Modelling growth of Ruppia cirrhosa. Aquatic Botany $68,29-44$

Cancela da Fonseca, L., 1989. Estudo da influência da "abertura ao mar" sobre um sistema lagunar costeiro: a lagoa de Santo André. Ph.D. thesis, University of Lisbon, Portugal, unpublished.

Cancela da Fonseca, L., Bernardo, J.M., Costa, A.M., Falcão, M., Vale, C., 2001. Seasonal chemical changes and eutrophication of a land-locked coastal lagoon (St. André, SW Portugal). Boletim do Museu Municipal do Funchal 6, 167-183.

Cancela da Fonseca, L., Costa, A.M., Bernardo, J.M., 1989. Seasonal variation of benthic and fish communities in a shallow land-locked coastal lagoon (St. André, SW Portugal). Scientia Marina 53, 663-669.

Cancela da Fonseca, L., Costa, A.M., Magalhães, F., Cristo, M., 1999. The benthic macroinvertebrate community of lagoa da Sancha: a coastal lagoon in SW Portugal. Limnetica 16, 39-48.

Carvalho, S., Pereira, P., Pereira, F., Pablo, H., Vale, C., Gaspar, M.B., 2011. Factors structuring temporal and spatial dynamics of macrobenthic communities in a eutrophic coastal lagoon (Óbidos lagoon, Portugal). Marine Environmental Research 71, 97-110.

CEZH/RNLSAS, 2004. Reserva Natural das Lagoas de St. ${ }^{\circ}$ André e Sancha, uma contribuição para o plano de gestão. Technical Report, Instituto da Conservação da Natureza/Centro de Zonas Húmidas, Portugal, unpublished.

Chainho, P., Costa, J.L., Chaves, M.L., Dauer, D.M., Costa, M.J., 2007. Influence of seasonal variability in benthic invertebrate community structure on the use of biotic indices to assess the ecological status of a Portuguese estuary. Marine Pollution Bulletin 54, 1586-1597.

Clarke, K.R., Somerfield, P.J., Chapman, M.G., 2006. On resemblance measures for ecological studies, including taxonomic dissimilarities and a zero-adjusted Bray-Curtis coefficient for denuded assemblages. Journal of Experimental Marine Biology and Ecology 330, 55-80.

Colombo, G., 1977. Lagoons. In: Barnes, R.S.K. (Ed.), The Coastline. John Wiley and Sons, Chichester, pp. 63-82.

Costa, A.M., Cristo, M., Cancela da Fonseca, L., 2003. Annual cycle of the benthic community of a coastal lagoon: lagoa de Melides (Grândola, SW Portugal). Revista de Biologia (Lisbon) 21, 71-89.

Costanza, R., D’Arge, R., de Groot, R., Farber, S., Grasso, M., Hannon, B., Limburg, K. Naeem, S., O’Neill, R.V., Paruelo, J., Raskin, R.G., Sutton, P., van den Belt, M., 1997. The value of the world's ecosystem services and natural capital. Nature 387, 253-260.

Cunha, M.R., Moreira, M.H., 1993. Macrobenthos of Potamogeton and Myriophyllum beds in the upper reaches of Canal de Mira (Ria de Aveiro, NW Portugal): community structure and environmental factors. Netherlands Journal of Aquatic Ecology 29, 377-390.

Dauer, D.M., 1993. Biological criteria, environmental health and estuarine macrobenthic community structure. Marine Pollution Bulletin 26, 249-257.

Dauvin, J.C., 2007. Paradox of estuarine quality: benthic indicators and indices, consensus or debate for the future. Marine Pollution Bulletin 55, 271-281.

Desmond, J.S., Deutschman, D.H., Zeuler, J.B., 2002. Spatial and temporal variation in estuarine fish and assemblages: analysis of an 11-year data Set invertebrate. Estuaries 25, 552-569.

Diamond, J.M., May, R.M., 1976. Island biogeography and the design of natural reserves In: May, R.M. (Ed.), Theoretical Ecology. Blackwell, Oxford, pp. 163-186.

Dieleman, J., 1979. Swimming rhythms, migration and breeding cycles in the estuarine Amphipods Gammarus chevreuxi and Gammarus zaddachi. In Naylor, E., Hartnoll, R.G. (Eds.), Cyclic Phenomena in Marine Plants and Animals. Pergamon Press, Oxford, pp. 415-422.

Duarte, P., Macedo, M.F., Cancela da Fonseca, L., 2006. The relationship between phytoplankton diversity and community function in a coastal lagoon. Hydrobiologia 555, 3-18.

Elliott, M., Quintino, V., 2007. The estuarine quality paradox. Environmenta homeostasis and the difficulty of detecting anthropogenic stress in naturally stressed areas. Marine Pollution Bulletin 54, 640-645.

Freitas, M.C., Cruces, A., Andrade, C., 1999. As Lagunas de Melides e de Santo André: Evolução e Comportamento Morfodinâmico. In: Carvalho, G., Gomes, F.V. Pinto, F.T. (Eds.), A zona costeira do Alentejo. Proceedings of Seminário sobre a Zona Costeira do Alentejo. Sines, Portugal, pp. 27-44.
Gamito, S., 2008. Three main stressors acting on the Ria Formosa lagoonal system (Southern Portugal): physical stress, organic matter pollution and the land-ocean gradient. Estuarine, Coastal and Shelf Science 77, 710-720.

Grall, J., Glémarec, M., 1997. Using biotic indices to estimate macrobenthic community perturbations in the Bay of Brest. Estuarine, Coastal and Shelf Science 44, 43-53.

Guelorget, O., Perthuisot, J.-P., 1983. Le domaine paralique. Expression géologiques, biologiques du confinement. Travaux du Laboratoire de Géologie de l'Ecole Normale Supérieure, Paris 16, France, 136 pp.

Hilly, C., Le Bris, H., Glémarec, M., 1986. Impacts biologiques des emissaries urbains sur les écosystèmes benthiques. Oceanis 12, 419-426.

Koutsoubas, D., Dounas, C., Arvanitidis, C., Kornilios, S., Petihakis, G., Triantafyllou, G., Eleftheriou, A., 2000. Macrobenthic community structure and disturbance assessment in Gialova Lagoon, Ionian Sea. ICES Journal of Marine Science 57, 1472-1480.

Lardicci, C., Rossi, F., 1998. Detection of stress on macrozoobenthos: evaluation of some methods in a coastal Mediterranean lagoon. Marine Environmental Research 45, 367-386.

MacArthur, R.M., 1972. Geographical Ecology. Patterns in the Distribution of Species. Harper \& Row Pub, New York, 270 pp.

Margalef, R., 1969. Diversity and stability: a practical proposal and a model of independence. Brookhaven Symposia in Biology 22, 25-37.

McCullagh, P., Nelder, J.A., 1989. Generalized Linear Models. Chapman and Hall, London, $532 \mathrm{pp}$.

Medeiros, J.P., Chaves, M.L., Silva, G., Azeda, C., Costa, J.L., Marques, J.C., Costa, M.J., Chainho, P., 2011. Benthic condition in low salinity areas of the Mira estuary (Portugal): lessons learnt from freshwater and marine assessment tools. Ecological Indicators. doi:10.1016/j.ecolind.2011.09.008.

Mistri, M., Fano, E.A., Rossi, G., Caselli, K., Rossi, R., 2000. Variability in macrobenthos communities in the Valli di Comacchio, northern Italy, a hypereutrophized lagoonal ecosystem. Estuarine, Coastal and Shelf Science 51, 599-611.

Mistri, M., Rossi, R., Fano, E.A., 2001. Structure and secondary production of a soft bottom macrobenthic community in a brackish lagoon (Sacca di Goro, northeastern Italy). Estuarine, Coastal and Shelf Science 52, 605-616.

Muus, B.J., 1967. The fauna of Danish estuaries and lagoons. Distribution and ecology of dominating species in the shallow reaches of the mesohaline zone. Meddelelser fra Danmarks Fishkeri-Havundersøgelser 5 (1), 1-136.

Newton, A., Icelyb, J.D., Falcão, M., Nobre, A., Nunes, J.P., Ferreira, J.G., Vale, C., 2003. Evaluation of eutrophication in the Ria Formosa coastal lagoon, Portugal. Continental Shelf Research 23, 1945-1961.

Nowicki, B.L., Nixon, S.W., 1985. Benthic community metabolism in a coastal lagoon ecosystem. Marine Ecology Progress Series 22, 21-30.

Pearson, T.H., Rosenberg, R., 1978. Macrobenthic succession in relation to organic enrichment and pollution of the marine environment. Oceanography and Marine Biology: An Annual Review 16, 229-311.

Pinto, R., Patricio, J., Baeta, A., Fath, B.D., Neto, J.M., Marques, J.C., 2009. Review and evaluation of estuarine biotic indices to assess benthic condition. Ecological Indicators 9, 1-25

Piscart, C., Moreteau, J.-C., Beisel, J.-N., 2005. Biodiversity and structure of macroinvertebrate communities along a small permanent salinity gradient (Meurthe River, France). Hydrobiologia 551, 227-236.

Quintino, V., Rodrigues, A.M., 1989. Environmental gradients and distribution of macrozoobenthos in three Portuguese coastal systems: Obidos, Albufeira and Alvor. In: Ryland, J.S., Tyler, P.A. (Eds.), Reproduction, Genetics and Distributions of Marine Organisms. Olsen and Olsen, Fredensborg, Denmark, pp. 441-450.

Quintino, V., Elliott, M., Rodrigues, A.M., 2006. The derivation, performance and role of univariate and multivariate indicators of benthic change: case studies at differing spatial scales. Journal of Experimental Marine Biology and Ecology 330, 368-382.

R Development Core Team, 2005. R: A Language and Environment for Statistical 609 Computing. R Foundation for Statistical Computing, Vienna, Austria. http:// www.R-project.org. ISBN: 6103900051070.

Serpa, D., Falcão, M., Duarte, P., Cancela da Fonseca, L., Vale, C., 2007. Evaluation of ammonium and phosphate release from intertidal and subtidal sediments of a shallow coastal lagoon (Ria Formosa - Portugal): a modelling approach. Biogeochemistry 82, 291-304.

Shannon, C.E., Weaver, W., 1963. The Mathematical Theory of Communication. University Illinois Press, Urbana, IL, USA, 117 pp.

Subida, M.D., Cunha, M.R., Moreira, M.H., 2005. Life history, reproduction, and production of Gammarus chevreuxi (Amphipoda: Gammaridae) in the Ria de Aveiro, northwestern Portugal. Journal of the North American Benthological Society 24, 82-100.

Taylor, D.I., Nixon, S.W., Granger, S.L., Buckley, B.A., 1999. Responses of coastal lagoon plant communities to levels of nutrient enrichment: a mesocosm study. Estuaries 22, 1041-1056

Taylor, D.I., Nixon, S.W., Granger, S.L., Buckley, B.A., McMahon, J.P., Lin, H.-J., 1995. Responses of coastal lagoon plant communities to different forms of nutrient enrichment a mesocosm experiment. Aquatic Botany 52, 19-34.

ter Braak, C.J.F., 1986. Canonical correspondence analysis: a new eigenvector technique for multivariate direct gradient analysis. Ecology 67, 1167-1179.

Weisberg, S.B., Ranasinghe, J.A., Dauer, D.M., Schaffner, L.C., Diaz, R.J., Frithsen, J.B., 1997. An estuarine benthic index of biotic integrity (B-IBI) for Chesapeake Bay. Estuaries 20, 149-158.

Zajac, R.N., Whitlatch, R.B., 1982. Responses of estuarine infauna to disturbance. I Spatial and temporal variation of recolonization. Marine Ecology Progress Series $10,1-14$.

Zettler, M.L., Schiedek, D., Bobertz, B., 2007. Benthic biodiversity indices versus salinity gradient in the southern Baltic Sea. Marine Pollution Bulletin 55, 258-270. 